\title{
Foreign Exchange Reserves of Central Banks and European Central Bank as an Important Element of the Concept of Sustainable Development
}

DOI: $10.26466 /$ opus. 886596

$*$

\author{
Paweł Sitek* \\ * Associate Professor, University of Economics and Human Sciences in Warsaw \\ E-Posta: p.sitek@vizja.pl ORCID: 0000-0002-4625-8803
}

\begin{abstract}
The aim of the article is to analyze the foreign exchange reserves of the European Central Bank in connection with the concept of sustainable development. The concepts of sustainable development are described in literature broadly and, for example, it is worth pointing to international and European concepts for sustainable development. The challenge for the international community has become the need to secure the environment for both present and future generations (implementation of the principle of intergenerational justice). As a result of the study, it was proven that, when implementing the foreign reserve management policy, the European Central Bank and national central banks should pursue the objectives of the current monetary policy for future generations. The interdisciplinary character of the articles implies different research methods: the importance and impact of sustainable development on a given country / region can be analyzed using a variety of methods, including statistical, surveys or dogmatic law. The analysis carried out as part of the study indicates that management of foreign exchange reserves of ECB has impact on the sustainable development and intergenerational justice.
\end{abstract}

Keywords: Sustainable development, Central Bank, European Central Bank, Foreign Exchange Reserves, Banking law, Intergenerational justice 
ISSN:2528-9527

E-ISSN: 2528-9535

Yıl Year: 11

Cilt Volume: 18

Sayı Issue: Yönetim ve Organizasyon Özel Sayısı

Temmuz July 2021

Uluslararası Toplum Araştırmaları Dergisi International Journal of Society Researches

Makalenin Geliş Tarihi Received Date: 21/02/2021

Makalenin Kabul Tarihi Accepted Date: 03/05/2021

\section{Sürdürülebilir Kalkınma Anlayışının Önemli Bir Elemanı Olarak Merkez Bankaları ve Avrupa Merkez Bankası Döviz Rezervleri}

*

Öz

Bu makalenin amacı, sürdürülebilir kalkınma kavramıyla bă̆lantılı olarak Avrupa Merkez Bankası'nın döviz rezervlerini analiz etmektir ve bu rezervlerin yapısını anlamaya çalışmaktır. Sürdürülebilir kalkınma kavramı ve ilgili konular literatürde geniş bir şekilde tanımlanmıştır buna ek olarak; sürdürülebilir kalkınma için uluslararası ve Avrupa kavramlarına işaret etmenin önemi üzerinde durulmuştur. Uluslararası toplum için meydan okuma, hem şimdiki hem de gelecek nesiller için çevreyi güvence altına alma ihtiyacı haline gelmesiyle önemli bir konu haline gelmiştir (kuşaklar arası adalet ilkesinin uygulanması). Yapılan çalışma sonucunda, Avrupa Merkez Bankası ve ulusal merkez bankalarının döviz rezerv yönetimi politikasını uygularken gelecek nesiller için mevcut para politikasının hedeflerini takip etmesi gerektiği kanıtlanmıştır. Makalelerin disiplinler arası karakteri, farklı araştırma yöntemlerini içermesiyle kritik bir noktada bulunmaktadır: belirli bir ülke/bölge üzerindeki sürdürülebilir kalkınmanın önemi ve etkisi, istatistiksel, anketler veya dogmatik hukuk dâhil olmak üzere çeşitli yöntemler kullanılarak analiz edilebilir. Çalışma kapsamında gerçekleştirilen analiz, ECB'nin döviz rezervlerinin yönetiminin sürdürülebilir kalkınma ve nesiller arası adalet üzerinde etkisi olduğunu göstermektedir.

Anahtar Kelimeler: Sürdürülebilir kalkınma, Merkez Bankası, Avrupa Merkez Bankası, Döviz Rezervleri, Bankacılık hukuku, kuşaklararası adalet 


\section{Introduction}

The purpose of the article is to analyze the foreign exchange reserves of the European Central Bank in connection with the concept of sustainable development, taking into account the interaction between each other: the economic sphere, the social sphere, the environmental sphere and the institutional and political sphere.

Basic source of national law regulating sustainable development is Art. 3 point 32 and 50 of the Act of 27 April 2001 Environmental Protection Law. ("Act of 27 April 2001 Environmental Protection Law (Dz. U. z 2019 r. poz. 1396 z późn.zm.), 2001)

An important international source of law in shaping the concept of sustainable development is the 1992 Rio Declaration of Rio de Janeiro on environment and development adopted by 180 countries of the world as part of the Earth Summit, Agenda 21 (Action Programme - Agenda 21) ${ }^{1}$ and UNECE Convention on Access to Information, Public Participation in Decision-making and Access to Justice in Environmental Matters (Aarhus Convention) signed on 25 June1998 in Aarhus, in Denmark. ${ }^{2}$

In European terms, the main objectives of the concept of sustainable development that it sets for EU countries are contained in the EU Commission Document. ("The European Semester," n.d.).

The starting point for the legal analysis of sustainable development in Polish law is art. 5 of the Constitution of the Republic of Poland "The Republic of Poland shall safeguard the independence and integrity of its territory and ensure the freedoms and rights of persons and citizens, the security of the citizens, safeguard the national heritage and shall ensure the protection of the

\footnotetext{
${ }^{1}$ Agenda 21 is a program document that presents how to develop and implement sustainable development programs in local life. This document was adopted at the "Environment and Development" conference on the initiative of the United Nations in 1992 at the Second Conference in Rio de Janeiro. Its Polish version was published in 1993 in the document "Final documents of the United Nations Conference on Environment and Development.

${ }^{2}$ Convention on Access to Information, Public Participation in Decision Making and Access to Justice in Environmental Matters, signed on June 25, 1998 in Aarhus, Denmark, during the 4th Pan-European Conference of Ministers for Environmental Protection. The Convention entered into force on October 30 , 2001. Poland ratified it in 2003. The Aarhus Convention has a special position in international law because it regulates human rights to a clean environment. The right to information, to participate in decisionmaking and access to justice in environmental protection are often referred to as the "next generation" of human rights and as such are a key element in implementing the principle of sustainable development.
} 
natural environment pursuant to the principles of sustainable development. ("The Constitution of the Republic of Poland of 2nd April, 1997 (As Dz. U. No. 78, item 483).," 1997). It should be noted that political and socioeconomic goals are often included in the Preambles to the Constitution or the first articles that refer to the past, but at the same time outline visions of the future. The doctrine emphasizes that the principle of sustainable development is an independent system principle. From the content of art. 5 shows, however, that it is instrumental in the sense that public authorities should be guided by it when conducting state policy (Safjan M., Bosek L., 2016). The Constitutional Tribunal stated that "the principles of sustainable development include not only the protection of nature or the shaping of spatial order, but also due care for social and civilization development, related to the need to build an appropriate infrastructure necessary for the life of man and individual communities, taking into account civilization needs. The idea of sustainable development thus includes the need to take into account various constitutional values and to balance them accordingly" (judgment of the Constitutional Tribunal of 6.6.2006, K 23/05, OTK-A 2006, No. 6, item 62, n.d.). Legal science emphasizes that the goal of sustainable development is to preserve the environment in a state ensuring its use by present and future generations "while maintaining the durability of the functioning of natural processes and biodiversity covering all levels: gene, species, landscape and ecosystem (Banaszak, 2012). However, it should be pointed here that actions taken by states should take into account not only the natural environment, but also the state of the economy and state finances.

The abovementioned sources of Polish, European and international law relating to sustainable development are only a necessary indication of the basic framework needed for further analysis around the main purpose of this article.

One of the four most important spheres included in the concept of sustainable development is economic order harmonized with the other three and conditioning the possibility of implementing the other three spheres, that is: the social sphere, the environmental sphere and the institutional and political sphere.

The economic sphere is considered to have been achieved in the following cases: 1 . Economic development expressed at a satisfactory 
level, 2. Employment in quantities guaranteeing social well-being, 3. Innovation objectively guaranteeing the competitiveness of goods and services traded by entrepreneurs, and 4. Transport ensuring proper freedom of movement of goods within the EU trade. The proper functioning of economic order with the sensitive areas defined in this way depends on obtaining the necessary foundations from other spheres, e.g. from the institutional and political side.

In proven world democracies, it has been accepted that in the proper development of economic order, it is necessary to have an independent central bank. The independent central bank includes guaranteeing an appropriate constitutional position and constitutionally entrusting with the achievement of the overarching goal of: ensuring a stable price level. Independent central banks in law-abiding countries carry out their most important task as part of their monetary policy, in which foreign exchange reserves play a crucial role.

\section{Materials and Methods}

The innovative element of the article is a combination of two apparently different subjects in one topic: from the field of banking and financial law and the concept of sustainable development, which emphasizes the multilateralism and the absorbency of the concept of sustainable development. Therefore, research methods are also characteristic for various disciplines of social sciences: from typically legal methods, such as analysis of legal regulations and doctrines, which make up a full understanding of law, through analysis of financial and statistical data published by banking and monetary institutions, up to analysis of press statements to show the latest legal and factual status. Legal-dogmatic methods and data analysis were supported by the descriptive method, which contributed to the conclusions summarizing the study. The author based on current, official data published on institutions' websites.

\section{The Issue of Foreign Exchange Reserves}

The purpose of the article is to analyze changes in the approach to the currency reserves of the European Central Bank (hereinafter: the ECB) at 
the turn of the 20th and 21st centuries, taking into account changes taking place in central banks outside the euro area, including the activities of the National Bank of Poland (hereinafter the NBP) and needs of the future generations and their capacity to pay debts of previous generations.

The European Central Bank (ECB) is responsible for conducting the monetary policy of the euro area - the largest economy in the world after the USA.

The legal basis for the European Union's common monetary policy is the Treaty on the Functioning of the European Union("Consolidated versions of the Treaty on European Union and the Treaty on the Functioning of the European Union (Journal of Law 2012/C 326/01).,"' 2012) and the Statute of the European System of Central Banks and of the European Central Bank.("Protocol (No. 4) on the Statute of the European System of Central Banks and of the European Central Bank, (Journal of Law 26.10.2012, C 326/230).," 2012) Pursuant to the Statute, the ECB and the European System of Central Banks (ESCB) were created simultaneously on June 1, 1998. The ECB, a key institution of the Eurosystem and the ESCB, cooperates in the implementation of the tasks entrusted with the national central banks. It is worth adding that the ECB is a legal person under international law.

In accordance with Article 127 (1) and Article 282 (2) of the Treaty on the Functioning of the European Union, the main objective of the ESCB is to maintain price stability. Without prejudice to the goal of price stability, the ESCB shall support general economic policies in the Union with a view to contributing to the achievement of the Union's objectives as set out in Article 3 of the Treaty on European Union. The ESCB operates in accordance with the principle of an open market economy with free competition, favoring the efficient allocation of resources, and in accordance with the principles set out in Article 119 of the Treaty on the Functioning of the European Union.

At the end of 2018, the entire Eurosystem had a total of official reserve assets totaling EUR 719 billion, including the ECB's official reserve assets. As indicated by this figure, the national central banks have significant additional official reserves in addition to those held by the ECB. The national central banks have full autonomy in the management of their official reserve assets in terms of asset allocation, risk / return profile and 
management style, and have multiple investment objectives for assets. While the ECB's official reserve assets can be considered the most liquid Eurosystem tranche that would be used as the first pool of reserves to finance any currency intervention, the official reserves held by the national central banks can be seen as separate and autonomous investment tranches. Nevertheless, it is in accordance with the Statute of the European System of Central Banks. ("The Statute of the European System of Central Banks and of the European Central Bank.," 2016) Part of these reserves should be readily available for intervention in the short term.

\section{Management of the ECB's Foreign Reserves}

The ECB's foreign reserve management investment framework is designed to ensure that it is readily available for sustainable development policies. The objectives of investing in managing the ECB's foreign reserve portfolio are, in order of importance, liquidity, security and return. Investment liquidity has priority to achieve the main objective of the ECB's foreign reserves, which is to ensure that the ECB can carry out foreign exchange operations at any time, when needed. This means that it must be possible to convert the portfolio into cash balances in a short time and with minimal costs. To achieve this, a large proportion of foreign exchange reserves are invested in US and Japanese government bonds with a relatively short residual maturity. They are considered the most liquid instruments available in their currencies. In addition, the high creditworthiness of issuers and the relatively short duration of portfolios serve the second investment principle: the retention of the ECB's foreign reserve capital. Subject to the principles of liquidity and security, the investment framework aims to maximize return on investment. For this purpose, the Eurosystem: 1) uses active portfolio management with incentives to use the allocated risk budget; and 2) allows the use of investment instruments that give a spread on government bonds or facilitate the expression of investment views. These include supranational and agency bonds, money market futures and bonds, commercial bank deposits, repos and reverse repos, secured currency swaps and interest 
rate swaps. Investments in each of these instruments are subject to risk management limits.

\section{Impact of Foreign Reserves on Sustainable Development}

Sustainable development is still a current and sensitive concept. The importance of the concept of sustainable development results from its interdisciplinary character and its future significance.

The EU Commission Communication adopted in 2016 on the next steps towards a sustainable future for Europe combines the sustainable development goals set out in the United Nations Agenda 2030for Sustainable Development with the European policy framework to ensure that all EU policies and initiatives - implemented within the EU and around the world - take sustainable development goals into account from the very beginning.

The concepts of sustainable development are described in literature broadly and, for example, it is worth pointing to international and European concepts for sustainable development. The challenge for the international community has become the need to secure the environment for both present and future generations (implementation of the principle of intergenerational justice).

The importance and impact of sustainable development on a given country / region can be analyzed using a variety of methods, including statistical, surveys or dogmatic law. Methods and indicators are used when analyzing sustainable development adequate to a specific scientific discipline. The doctrine suggests analyzing sustainable developments indicators according to 4 spheres of impact: social, economic, environmental and institutional-political sphere. They are divided into subsections: 1. Social order: 1.1. Demographic change, 1.2. Public health, 1.3. Social integration, 1.4. Education, 1.5. Access to the labor market, 1.6. Public security, 1.7. Sustainable consumption patterns, 2. Economic governance: 2.1. Economic development, 2.2. Employment, 2.3. Innovation, 2.4. Transport, 2.5. Sustainable production patterns, 3. Environmental governance: 3.1. Climate change, 3.2. Energy, 3.3. Air protection, 3.4. Marine ecosystems, 3.5 Fresh water resources, 3.6. Land use, 3.7. Biodiversity, 3.8. Waste management, and 4. Institutional and 
political governance: 4.1. Global partnership, 4.2. Cohesion and efficiency policy, 4.3. Openness and participation, 4.4. citizens' activity.

Despite several decades of tradition of using the concept of sustainable development, it still remains a challenge. The challenge for humanity is to guarantee survival, as well as to secure living conditions for future generations. Since the adoption of the direction of capital harmonization (sustainable development), four orders, i.e. social order, economic order, environmental order and institutional and political order have been difficult to achieve harmoniously in individual countries and continents. According to the author, the European Central Bank, through its activities has influenced the economic order in the European Union so much that it strengthened the implementation of the other three orders. The beginning of the 21st century forced a new discussion about the architecture of global banking and the management of foreign exchange reserves. In the author's opinion, none of the orders can be continued in the event of a collapse of monetary and financial systems.

\section{Summary}

The concept of sustainable development in Europe and the world still leaves big challenges for the present generation. Current generations assuming that the concept of sustainable development is a fundamental idea but also a specific challenge. The challenge to guarantee humanity's survival and, above all, to secure living conditions for future generations. Since the adoption of the concept of sustainable development understood as balance between four orders, i.e. social order, economic order, environmental order and institutional and political order - all major European and world institutions have strived to harmoniously implement these orders.

In properly functioning democracies of world countries, it is unanimously recognized that in the proper development of economic order, it is necessary to operate an independent central bank. The independent central bank must have a guaranteed political position in the constitution. Only such a central banking architecture is capable of achieving the overarching goal of: ensuring a stable price level. As discussed above, independent central banks are able to perform the most 
important task within the framework of their monetary policy, through proper management of foreign exchange reserves.

It should be remembered that sustainable development is a way of management, in which meeting the needs of the present generation cannot reduce the chances of meeting the needs of future generations. In this context, when implementing the foreign reserve management policy, the European Central Bank and national central banks should pursue the objectives of the current monetary policy for future generations. Foreign exchange reserves are a special good that only the current generation and the current government cannot use. On the contrary, the generations that have their representatives in the central authorities are obliged to manage foreign exchange reserves taking into account the need for financial security of future generations.

\section{References}

Act of 27 April 2001 Environmental Protection Law (Dz. U. z 2019 r. poz. 1396 z późn.zm.), 2001.

Banaszak, B. (2012). Konstytucja Rzeczypospolitej Polskiej. Komentarz, 2nd ed. Warszawa.

Consolidated versions of the Treaty on European Union and the Treaty on the Functioning of the European Union (Journal of Law 2012/C 326/01)., 2012.

Judgment of the Constitutional Tribunal of 6.6.2006, K 23/05, OTK-A 2006, No. 6 , item 62 , n.d.

Protocol (No. 4) on the Statute of the European System of Central Banks and of the European Central Bank, (Journal of Law 26.10.2012, C 326/230)., 2012.

Safjan M., Bosek L., (2016). Konstytucja RP. Tom I. Komentarz do art. 1-86. C.H. Beck, Warszawa.

The Constitution of the Republic of Poland of 2nd April, 1997 (As Dz. U. No. 78, item 483)., 1997.

The European Semester [WWW Document], n.d. URL https://ec.europa.eu/info/business-economy-euro/economic-andfiscal-policy-coordination/eu-economic-governance-monitoringprevention-correction/european-semester_pl (accessed 4.28.20).

The Statute of the European System of Central Banks and of the European Central Bank., 2016. 


\section{Citation Information}

Sitek, P. (2021). Foreign exchange reserves of central banks and European central bank as an important element of the concept of sustainable development. OPUS-International Journal of Society Researches, 18(Yönetim ve Organizasyon Özel Sayıs1), 1785-1795. DOI: 10.26466/opus.886596. 